\title{
Testing BIST for Equity Return Anomalies using ARDL Model
}

\section{Tuna Can GÜLEÇ (iD) a}

a Manisa Celal Bayar University, Faculty of Applied Sciences, Department of Banking and Finance, Turkey tunacan.gulec@cbu.edu.tr

\begin{tabular}{|c|c|}
\hline ARTICLE INFO & ABSTRACT \\
\hline Keywords: & Purpose - This study analyzes the Borsa İstanbul against equity return anomalies. With this \\
\hline $\begin{array}{l}\text { Financial Anomaly } \\
\text { Volatility }\end{array}$ & $\begin{array}{l}\text { purpose, the role of key financial stability indicators on long and short-term volatility movements } \\
\text { in Borsa Istanbul has been tested. }\end{array}$ \\
\hline Stock Market & Design/methodology/approach - The model used in the study attempts to explain the volatility in \\
\hline BIST & stock prices using Return on Equity, Equity Ratio, and Net forex position over net income. Zivot \\
\hline ARDL & $\begin{array}{l}\text { Andrews and ARDL bounds tests have been conducted on the series and cointegration relationships } \\
\text { between all of the companies are detected. Following this, long term ARDL models and Error }\end{array}$ \\
\hline Received 5 October 2020 & $\begin{array}{l}\text { correction models have been implemented on each of the series. The data set used in the study covers } \\
\text { the period between 2000Q3-2019Q4 at the quarterly frequency. } 5 \text { companies are selected out of the }\end{array}$ \\
\hline Revised 27 December 2020 & BIST100 index with the highest price maturity, excluding the financial institutions. \\
\hline Accepted 2 March 2021 & $\begin{array}{l}\text { Findings - Results of the study indicate that both Return on Equity and Equity Ratio have } \\
\text { statistically significant, inverse relationships with the analyzed companies both long and in short } \\
\text { term. However, for the companies used in the study, the net forex position had no significant effect. }\end{array}$ \\
\hline Article Classification: & Discussion - As the majority of the stock price volatilities are affected negatively by the equity \\
\hline Research Article & $\begin{array}{l}\text { return factors, the findings of the study reject the existence of a market-wide equity return anomaly } \\
\text { in the Turkish stock market. However, the net forex position is one of the most significant risk factors } \\
\text { for the Turkish firms and as findings indicate, it is alarming that it plays no part at all in the } \\
\text { investment decisions. }\end{array}$ \\
\hline
\end{tabular}

\section{Introduction}

In the finance theory, an increase in risk should be rewarded with an increase in investment returns. In an economy that is dependent on foreign investment such as Turkey, expecting a perfect market efficiency in the stock market is not realistic. However, maintaining at least a certain level of financial stability is fundamental in stimulating market growth. In this regard, one of the most influential factors is equity adequacy. A firm's level of equity against its profit generation capacity must be aligned with the fundamental principles of the finance theory. In other words, firms that are excessively using leverage and are running low on equity adequacy should be punished by the market. This punishment can be in 2 forms, either its market value would drop accordingly, or a higher level of return is expected from its indebtments in the future. If this is not the case, it poses a significant risk in the market and we can suggest that there is an equity return anomaly in the market.

The existence of equity return anomalies is one of the most detrimental structural risks for the stock market, causing discrepancies between the intrinsic value of stocks and the market price. These discrepancies might result in price bubbles or even market crashes in the long run. In this study, 5 companies out of the BIST 100 index are tested for these anomalies over 19 years. For the analysis purposes, the market price is considered as the representative of the market perception of the underlying firm. Reliable companies are expected to have fewer fluctuations in the market perception on average compared to the less reliable companies. These fluctuations are represented in the model under the "volatility" variable. As will be demonstrated in detail in the research model, other universally accepted indicators of financial stability that are used in the model are the equity ratio and the return on equity.

The equity ratio is significant in the sense that it represents the leverage of the company and companies with higher debt levels are expected to have a higher Beta compared to the market as comprehensively supported by the literature(Faff et al., 2002; Fernandez, 2006; Sari \& Hutagaol, 2009). As the return on equity represents 
the firm's efficiency in the use of its equity, this variable has been into the model to represent the firm's profit capability in comparison to its equity size. The last and the most debatable variable in the model is the foreign currency-denominated debts of the company. This variable is especially significant for Turkey due to the high levels of private-sector debts denominated in foreign currencies. ARDL model is used in the analysis to be able to separate the difference of the effects in the short and long term separately.

Theoretically, under the perfect market conditions, all of the risk indicators are expected to have negative relationships with the market volatility in both the short-run and long-run. Similarly, the study assumes the existence of an extreme return anomaly if neither "Return on Equity" nor "Equity Ratio" can affect the firm volatility in any length of period.

\section{Literature Review}

There is extensive literature regarding the anomalies in Borsa İstanbul. The anomalies that focus specifically on the equity returns, however, are quite rare, and therefore, several studies that focus on the return anomalies are added to the review for comparison. Table 1 demonstrates a summary of the studies reviewed.

Table 1. Summary of Relevant Literature on Anomalies on BIST

\begin{tabular}{|c|c|c|}
\hline Autl & Type of Anomaly & Findings \\
\hline (A) & ies & t. \\
\hline (Azi & Acc & d. \\
\hline (Azimli, 2020) & Return Anomaly & $\begin{array}{l}\text { Above-average returns are not possible. Existenc } \\
\text { of Anomaly is Rejected }\end{array}$ \\
\hline (Cengiz e & Day of the week & $\begin{array}{l}\text { The study has found BIST to be an inefficient } \\
\text { market. }\end{array}$ \\
\hline (Çiçek, 2013) & $\begin{array}{l}\text { Day of the Week } \\
\text { Anomaly }\end{array}$ & $\begin{array}{l}\text { The study finds that only some of the BIST indexes } \\
\text { are affected by the anomaly. }\end{array}$ \\
\hline (Çıkrıkçı \& Ozyesil, 2018a) & Announcement Effect & The study finds evidence for the anomaly. \\
\hline (Çıkrıkçı \& Ozyesil, 2018b) & $\begin{array}{r}\text { Underperfor } \\
\text { Anoma }\end{array}$ & $\begin{array}{l}\text { Results indicate the existence of a long-term } \\
\text { Underperformance anomaly. }\end{array}$ \\
\hline (Çıkrıkçı & $\begin{array}{r}\text { Under } \\
\text { Ano }\end{array}$ & A partial anomaly has been detected. \\
\hline (Ergur & $\begin{array}{r}\text { Herd B } \\
\text { Anor }\end{array}$ & No evidence has 1 \\
\hline (Hayki & MAX Anon & $\mathrm{N}$ \\
\hline (Karavardar, 2014) & Benfo & BIST indexes are in accordance \\
\hline (Küçüksille \& Özmutaf, 2015) & $\begin{array}{r}\text { Ramadan } \\
\text { Anom }\end{array}$ & $\begin{array}{l}\text { anomaly specific to Ramadan } \\
\text { nd. }\end{array}$ \\
\hline (Sahin et & January Anomaly & maly is persistent in BIST \\
\hline (Toraman et al., 2017) & Day of Week Effect & d significant evidence of the \\
\hline (Uğu & Firm Size Anomaly & $\begin{array}{l}\text { Debatable evidence regarding anomalies has been } \\
\text { reported. }\end{array}$ \\
\hline (Altın \& Yazan, 2016) & Return Anomaly & $\begin{array}{l}\text { Significant evidence for price anomalies has been } \\
\text { reported. }\end{array}$ \\
\hline (Favilukis \& Zhang, 2019) & Pricing Anomalies* & Redefines anomalies detected by CAPM beta. \\
\hline (Ali \& B & Low Beta Anomaly* & \\
\hline $\begin{array}{l}\text { (Fang \& Olteanu-Veerman, } \\
\text { 2019) }\end{array}$ & $\begin{array}{l}\text { Equity Issuance } \\
\text { Anomaly * }\end{array}$ & $\begin{array}{l}\text { The study finds evidence on anomaly and discusses } \\
\text { its elements. }\end{array}$ \\
\hline (Wang, 2020) & Return Anomaly * & Evidence for return anomaly has been reported. \\
\hline
\end{tabular}

*Study is not conducted on Borsa İstanbul (BIST). 
The literature on the anomalies on BIST is mainly focused on calendar anomalies such as the day of the week effect or month of the year effect. The majority of these studies (Aksoy \& Ulusoy, 2015; Cengiz et al., 2017; Çiçek, 2013; Sahin et al., 2018) claim to have found evidence of the inefficiency of the Turkish markets in terms of market efficiency defined by Eugene Fama's efficient market hypothesis(Fama, 1970). These studies test the theory that the returns should not differentiate between certain calendar dates and should stay stable across different periods or dates. Testing for such claims requires ceteris-paribus conditions. But when testing in an open market, ceteris- paribus conditions are impossible to meet. Price variations might not be caused by just the calendar date but other periodic events. To confirm these relationships, causality tests may be required, linking variations on stock prices or returns to calendar month. However, all but a few studies skipped this crucial step. Some of the studies on BIST also focus on various non-calendar related anomalies. Such as herd behavior anomaly or accrual anomaly, however, theoretically, the pricing anomaly studies, and underperformance anomaly studies are the most similar ones to this study. These studies generally reported an efficient market in terms of return anomalies or pricing anomalies. When all studies are evaluated collectively, the findings indicate that BIST is far from being an efficient market and contains several inefficiency factors. However, there is an obvious gap in the literature when it comes to Equity return anomaly researches. The equity return anomaly is perhaps the most crucial one for Turkish markets mainly because of the macroeconomic structure of the financial system. Equity insufficiency or inefficiency are some of the most chronic problems in the Turkish economy. This study aims to fill these gaps by answering some of these questions.

\section{Dataset and Sample Selection}

The data set used in the study covers the period between 2000Q3-2019Q4 at the quarterly frequency. Going back further than 2001 would structurally break the series due to the drastic changes in the reporting procedures (IFRS) and the financial system reforms caused by the banking crisis in 2001.

The dataset excludes the financial institutions, therefore they have been selected among the BIST industrial index. In the next step in the selection of the sample, the aim was to determine the companies that reflect the market perception as dynamically as possible. Therefore, to reflect the price maturity, spot market activity and the short sale activity has been used in the model. Companies have been sorted from the most active to the least active using the following model:

Price Maturity Model:

$$
\text { Price Maturity: } \sum \frac{P_{\text {Max }}-P_{\text {Min }}}{S P_{M a x}-S P_{\text {Min }}}
$$

Where "P" represents the Spot Price and "SP" represents the Short Sale price for each trading day.

Among the index companies, 5 companies with the highest values of price maturity value have been selected as the sample for the analysis.

The companies used in the study are abbreviated to variables using their stock tickers as in Borsa Istanbul (BIST). Table 2 is a list of the names of these companies as used in the study and their respective stock tickers.

Table 2. The List Of Companies Used in The Study and Their Respective Stock Tickers.

\begin{tabular}{|c|c|}
\hline Company Name & Stock Ticker \\
\hline Arçelik A.Ş. & ARCLK \\
\hline Ereğli Demir ve Çelik Fabrikaları T.A.Ş. & EREGL \\
\hline Türkiye Petrol Rafinerileri A.Ş. & TUPRS \\
\hline Tofaş Türk Otomobil Fabrikası A.S. & TOASO \\
\hline Vestel Elektronik Sanayi ve Ticaret AS & VESTL \\
\hline
\end{tabular}

Table 3 demonstrates a summary of the variables used in the research model: 


\section{T. C. Güleç 13/1 (2021) 100-111}

Table 3. Summary of the Variables

\begin{tabular}{|c|c|c|}
\hline Variable Name & Expression & Abbreviated as \\
\hline Volatility & Std Dev.of $\left(\ln \frac{\text { Closing } \text { Price }_{n}}{\text { Closing } \text { Price }_{n-1}}\right)$ & Volatility \\
\hline $\begin{array}{c}\text { Foreign Currency } \\
\text { Borrowing Tendency }\end{array}$ & $\frac{\text { Net foreign exchange position }}{\text { EBITDA }}$ & FOREX_BORROW \\
\hline Equity Ratio & $\frac{\text { Total Equity }}{\text { Total Assets }}$ & EQ_RATIO \\
\hline Return on Equity & $\frac{\text { Net Income }}{\text { Shareholder's Equity }}$ & ROE \\
\hline
\end{tabular}

\section{Methodology and Analysis}

As the ARDL method will be used to analyze the series, a unit root test is conducted using the ZivotAndrews test. Results are demonstrated in Table 4:

Table 4. Results of the Zivot-Andrews Unit Root Test

\begin{tabular}{|c|c|c|c|c|}
\hline & Intercept & Breaking Date & Intercept and Trend & Breaking Date \\
\hline \multicolumn{5}{|c|}{ ARCLK } \\
\hline Volatility & $-8.2580(0)^{* * * *}$ & 01.09 .2003 & $-8.6034(0)^{* * 4+4}$ & 01.12 .2005 \\
\hline ROE & $-4.4015(4)$ & 01.06 .2009 & $-4.7576(4)$ & 01.06 .2009 \\
\hline ROE & $-7.8613(4)^{* * *+*}$ & 01.03 .2009 & $-7.9845(4)^{* * *+*}$ & 01.03 .2009 \\
\hline EQ_RATIO & $-3.7182(4)$ & 01.06 .2009 & $-3.8062(4)$ & 01.06 .2009 \\
\hline EQ_RATIO & $-6.3100(2)^{* * * *}$ & 01.03 .2009 & $-6.3632(2)^{k+4 *+}$ & 01.06 .2004 \\
\hline FOREX_BORROW & $-6.5880(1)^{* * * * *}$ & 01.12 .2008 & $-6.6559(1)^{* * *+*}$ & 01.12 .2008 \\
\hline \multicolumn{5}{|c|}{ EREGL } \\
\hline Volatility & $-4.7550(3)$ & 01.03 .2004 & $-4.7412(1)$ & 01.12 .2005 \\
\hline Volatility & $-8.6311(1)$ & 01.03 .2009 & $-8.9948(1)$ & 01.12 .2003 \\
\hline ROE & $-4.1125(4)$ & 01.12 .2008 & $-4.2096(4)$ & 01.12 .2008 \\
\hline ROE & $-11.4230(3)$ & 01.03 .2010 & $-11.3325(3)$ & 01.03 .2010 \\
\hline EQ_RATIO & $-3.2427(1)$ & 01.03 .2008 & $-3.4551(4)$ & 01.12 .2007 \\
\hline EQ_RATIO & $-12.7076(0)$ & 01.12 .2004 & $-13.4351(0)$ & 01.06 .2004 \\
\hline FOREX_BORROW & $-7.0993(0)$ & 01.12 .2006 & $-7.2288(0)$ & 01.12 .2006 \\
\hline \multicolumn{5}{|c|}{ TUPRS } \\
\hline Volatility & $-7.2555(0)$ & 01.06 .2005 & $-8.3569(0)$ & 01.06 .2005 \\
\hline ROE & $-7.0160(1)$ & 01.03 .2011 & $-7.0160(1)$ & 01.03 .2011 \\
\hline EQ_RATIO & $-3.2048(4)$ & 01.03 .2008 & $-2.8314(4)$ & 01.06 .2006 \\
\hline EQ_RATIO & $-9.4590(2)$ & 01.03 .2005 & $-10.4803(2)$ & 01.12 .2004 \\
\hline FOREX_BORROW & $-5.5147(2)$ & 01.12 .2014 & $-5.4323(1)$ & 01.03 .2015 \\
\hline \multicolumn{5}{|c|}{ TOASO } \\
\hline Volatility & $-7.1750(0)$ & 01.06 .2006 & $-7.7890(0)$ & 01.06 .2006 \\
\hline ROE & $-7.8657(3)$ & 01.09 .2012 & $7.7788(3)$ & 01.09 .2012 \\
\hline EQ_RATIO & $-3.1940(0)$ & 01.06 .2003 & $-4.6916(0)$ & 01.06 .2006 \\
\hline EQ_RATIO & $-10.9699(0)$ & 01.12 .2005 & $-11.1525(0)$ & 01.06 .2004 \\
\hline FOREX_BORROW & $-6.5017(2)$ & 01.03 .2007 & $-6.7053(2)$ & 01.0 .2007 \\
\hline \multicolumn{5}{|c|}{ VESTL } \\
\hline Volatility & $-4.2055(1)$ & 01.06 .2006 & $-4.7907(1)$ & 01.06 .2006 \\
\hline Volatility & $-8.9851(1)$ & 01.03 .2009 & $-9.2168(1)$ & 01.12 .2003 \\
\hline ROE & $-7.8284(0)$ & 01.06 .2006 & $-9.0103(0)$ & 01.06 .2009 \\
\hline OK_PASI & $-6.5627(1)$ & 01.06 .2009 & $-6.6916(1)$ & 01.03 .2015 \\
\hline FOREX_BORROW & $-5.7988(1)$ & 01.03 .2007 & $-5.9258(1)$ & 01.06 .2007 \\
\hline
\end{tabular}

Note: The values in the parenthesis show lag length. Critical values for Zivot-Andrews test statistic in the intercept are respectively $-5.34,-4.93,-4.58$ at $\% 1, \% 5$, and $\% 10$ significant levels. Critical values for Zivot- 
Andrews test statistics in the intercept and trend are respectively $-557,-5.08,-4.82$ at $\% 1, \% 5$, and \%10 significance levels. ${ }^{* * *},{ }^{* *},{ }^{*}$ respectively indicate significance at $\% 1, \% 5$ and $\% 10$ levels.

According to the test results reported in Table 2, For the ARCLK series, VOLATILITY and FOREX_BORROW variables are stationary in level[I(0)] for both Intercept and Intercept and Trend Unit Root Tests at $5 \%$ level of significance. On the other hand, ROE and EQ_RATIO variables become stationary at their $1^{\text {st }}$ differences[I(1)]. Having variables stationary at different levels suggests the ARDL as the most suitable method for the modeling process.

ARDL bounds test is based on the studies of Pesaran et.al. $(1999,2001)$. This method allows for the testing of cointegration between variables where variables are stationary at different levels. The model first establishes an unrestricted error correction model. In the example of our model, the effects of financial indicators on volatility has been modeled using an unrestricted error correction model as denoted in Research Model:

\section{Research Model:}

$$
\begin{aligned}
\Delta \text { VOLATILITY }_{i t} & =\beta_{0}+\beta_{1} \sum_{i=1}^{q} \Delta \text { VOLATILITY }_{t-i}+\beta_{2} \sum_{i=1}^{q} \Delta R O E_{t-i}+\beta_{3} \sum_{i=1}^{q} \Delta \text { EQ_RATIO }_{t-i} \\
& +\beta_{4} \sum_{i=1}^{q} \Delta \text { FOREX_BORROW }_{t-i}+\gamma_{1} \text { VOLATILITY }_{t-I}+\gamma_{2} \text { ROE }_{t-I}+\gamma_{3} \text { EQ_RATIO }_{t-I} \\
& +\gamma_{4} \text { FOREX_BORROW }_{t-I}+\varepsilon_{t}
\end{aligned}
$$

The null hypothesis that tests for the existence of a cointegration relation between variables in the research model is $H_{0}: \gamma_{1}=\gamma_{2}=\gamma_{3}=\gamma_{4}=0$. F statistic values have been compared with the bound values reported in the study of Pesaran (2001) for 1\%, 5\%, and 10\% levels of significance. Accordingly, if the F value is smaller than the lower bound, then it can be said that there is no cointegration between the variables. If the $F$ value is between then low and high bounds, then evidence of cointegration is found. And if the F value is greater than the high bound value reported in the article, then the existence of cointegration between variables can be suggested.

For the variables with cointegration properties, ARDL models have been used to determine long term and short-term coefficients. The short-term cointegration coefficients have been estimated after long-term coefficient calculations by using the relevant error correction models.

The first step in the analysis will be determining the optimal lag lengths for the error correction models. With a data set of quarterly frequency, the maximum lag length for each model has been set as 4 . For every level of lag length, AIC, SC, and HQ information criteria tests, Breusch-Godfrey LM autocorrelation tests and BreuschPagan heteroskedasticity tests have been conducted.

The optimal lag length is chosen among lengths with normal distribution and without auto-correlation or heteroskedasticity problems, where AIC, SC, and HQ values are minimum. Through these criteria, for every company, the optimal lag length is found to be " 1 ". After determining optimal lag lengths, F statistics have been calculated by using an unrestricted error correction model with a lag length of 1 .

Table 5 demonstrates the bounds test results for every company, along with the critical values in the study of

\begin{tabular}{|c|c|c|c|c|c|c|}
\hline \multicolumn{7}{|c|}{ ARCLK Long Term Model } \\
\hline & \multicolumn{2}{|c|}{ Lag Lengths } & \multicolumn{2}{|c|}{ F Statistic } & & \\
\hline \multicolumn{7}{|c|}{ Critical Values } \\
\hline Critical Values & \multicolumn{2}{|c|}{ \%10 Level of Significance } & \multicolumn{2}{|c|}{ \%5 Level of Significance } & \multicolumn{2}{|c|}{ \%1 Level of Significance } \\
\hline $\mathrm{K}$ & $\mathrm{I}(0)$ & $\mathrm{I}(1)$ & $\mathrm{I}(0)$ & $\mathrm{I}(1)$ & $\mathrm{I}(0)$ & $\mathrm{I}(1)$ \\
\hline 3 & 2.72 & 3.77 & 3.23 & 4.35 & 4.29 & 5.61 \\
\hline \multicolumn{7}{|c|}{ EREGL Long Term Model } \\
\hline & \multicolumn{2}{|c|}{ Lag Lengths } & \multicolumn{2}{|c|}{ F Statistic } & & \\
\hline & 1 & 8.1433 & & & & \\
\hline
\end{tabular}
Pesaran (2001):

Table 5. Bound Test Results 
T. C. Güleç 13/1 (2021) 100-111

\begin{tabular}{|c|c|c|c|c|c|c|}
\hline Critical Values & $\begin{array}{l}\text { \%10 Level of } \\
\text { Significance }\end{array}$ & $\begin{array}{l}\% 5 \text { Level of } \\
\text { Significance }\end{array}$ & $\begin{array}{l}\text { \%1 Level of } \\
\text { Significance }\end{array}$ & & & \\
\hline K & $\mathrm{I}(0)$ & $\mathrm{I}(1)$ & $\mathrm{I}(0)$ & $\mathrm{I}(1)$ & $\mathrm{I}(0)$ & $\mathrm{I}(1)$ \\
\hline 3 & 2.72 & 3.77 & 3.23 & 4.35 & 4.29 & 5.61 \\
\hline \multicolumn{7}{|c|}{ TUPRS Long Term Model } \\
\hline & \multicolumn{2}{|l|}{ Lag Lengths } & \multicolumn{2}{|l|}{ F Statistic } & & \\
\hline & 1 & & 7.1752 & & & \\
\hline Critical Values & \multicolumn{2}{|c|}{ \%10 Level of Significance } & \multicolumn{2}{|c|}{ \%5 Level of Significance } & \multicolumn{2}{|c|}{ \%1 Level of Significance } \\
\hline K & $\mathrm{I}(0)$ & $\mathrm{I}(1)$ & $\mathrm{I}(0)$ & $\mathrm{I}(1)$ & $\mathrm{I}(0)$ & $\mathrm{I}(1)$ \\
\hline 3 & 2.72 & 3.77 & 3.23 & 4.35 & 4.29 & 5.61 \\
\hline \multicolumn{7}{|c|}{ TOASO Long Term Model } \\
\hline & \multicolumn{2}{|l|}{ Lag Lengths } & \multicolumn{2}{|l|}{ F Statistic } & & \\
\hline & 1 & & 8.8779 & & & \\
\hline Critical Values & \multicolumn{2}{|c|}{ \%10 Level of Significance } & \multicolumn{2}{|c|}{ \%5 Level of Significance } & \multicolumn{2}{|c|}{ \%1 Level of Significance } \\
\hline K & $\mathrm{I}(0)$ & $\mathrm{I}(1)$ & $\mathrm{I}(0)$ & $\mathrm{I}(1)$ & $\mathrm{I}(0)$ & $\mathrm{I}(1)$ \\
\hline 3 & 2.72 & 3.77 & 3.23 & 4.35 & 4.29 & 5.61 \\
\hline \multicolumn{7}{|c|}{ VESTL Long Term Model } \\
\hline & \multicolumn{2}{|l|}{ Lag Lengths } & \multicolumn{2}{|l|}{ F Statistic } & & \\
\hline & 1 & & 5.5794 & & & \\
\hline Critical Values & \multicolumn{2}{|c|}{ \%10 Level of Significance } & \multicolumn{2}{|c|}{ \%5 Level of Significance } & \multicolumn{2}{|c|}{ \%1 Level of Significance } \\
\hline $\mathrm{K}$ & $\mathrm{I}(0)$ & $\mathrm{I}(1)$ & $\mathrm{I}(0)$ & $\mathrm{I}(1)$ & $\mathrm{I}(0)$ & $\mathrm{I}(1)$ \\
\hline 3 & 2.72 & 3.77 & 3.23 & 4.35 & 4.29 & 5.61 \\
\hline
\end{tabular}

Note: Critical bound values are based on F Table values in the study of Pesaran (2001). K represents the number of independent variables.

As seen in Table 3, at a 5\% level of significance, the F-test statistic values in the bound test results for all of the companies, are above both the maximum and the minimum bound values that are reported in the study of Pesaran (1997). This indicates a cointegration relationship between all of the companies. Hence, long term and short term coefficients for all companies are estimated using the ARDL model.

The ARDL model for the estimation of long term coefficients for all companies can be expressed as in the following model:

\section{ARDL Model:}

VOLATILITE $_{i t}=\beta_{0}+\beta_{1} \sum_{i=1}^{q}$ VOLATILITE $_{t-i}+\beta_{2} \sum_{i=0}^{p} R O E_{t-i}+\beta_{3} \sum_{i=0}^{r} O K_{-} P A S I F_{t-i}+\beta_{4} \sum_{i=0}^{m} \Delta Y P P P_{-} F O K_{t-i}+\varepsilon_{t}$

Proper lag lengths for the long term ARDL coefficient estimations are determined using the AIC information criterion.

Accordingly, the ARDL model estimation results including the long-term coefficients for all of the companies are reported in Table 6.

Table 6. The Long-Term ARDL Model Estimation Results

\begin{tabular}{|c|r|r|r|r|}
\hline \multicolumn{5}{|c|}{ ARCLK } \\
\hline \multicolumn{5}{|c|}{ ARDL(1,0,0) Model } \\
\hline Variables & Coefficient & Standard Dev. & T-Statistic & Prob. \\
\hline VOLATILITY(-1) & 0.544779 & 0.086634 & 6.288251 & 0.0000 \\
\hline ROE & -7.683335 & 2.992983 & -2.567117 & 0.0123 \\
\hline EQ_RATIO & 0.025460 & 0.015801 & 1.611350 & 0.1114 \\
\hline FOREX_BORROW & -0.006466 & 0.007681 & -0.841875 & 0.4026 \\
\hline C & 0.584535 & 0.603596 & 0.968421 & 0.3360 \\
\hline \multicolumn{7}{|c|}{ Calculated Long Term Coefficients } \\
\hline Variables & Coefficient & Standard Dev. & T-Statistic & Prob. \\
\hline
\end{tabular}


T. C. Güleç 13/1 (2021) 100-111

\begin{tabular}{|c|c|c|c|c|}
\hline ROE & -16.878254 & 6.975340 & -2.419703 & 0.0180 \\
\hline EQ_RATIO & 0.055930 & 0.034634 & 1.614893 & 0.1106 \\
\hline FOREX_BORROW & -0.014205 & 0.017006 & -0.835261 & 0.4063 \\
\hline $\mathrm{C}$ & 1.284068 & 1.286352 & 0.998224 & 0.3214 \\
\hline $\mathrm{R}^{2}$ & 0.4293 & \multicolumn{2}{|c|}{ Akaike Information Crit. } & 2.6786 \\
\hline Adjusted $\mathrm{R}^{2}$ & 0.3984 & \multicolumn{2}{|c|}{ Schwarz information criterion } & 2.8286 \\
\hline F-Statistic & 13.9168 & \multicolumn{2}{|c|}{ Durbin-Watson statistic } & 1.7244 \\
\hline \multicolumn{5}{|c|}{ EREGL } \\
\hline \multicolumn{5}{|c|}{ ARDL(1,0,0,1)Model } \\
\hline Variables & Coefficient & Standard Dev. & T-Statistic & Prob. \\
\hline VOLATILITY(-1) & 0.351713 & 0.082666 & 4.254624 & 0.0001 \\
\hline ROE & -9.755868 & 1.785739 & -5.463211 & 0.0000 \\
\hline EQ_RATIO & -0.011339 & 0.014594 & -0.777018 & 0.4397 \\
\hline FOREX_BORROW & -0.000577 & 0.001390 & -0.415342 & 0.6791 \\
\hline FOREX_BORROW (-1) & 0.002345 & 0.001408 & 1.665372 & 0.1001 \\
\hline $\mathrm{C}$ & 2.720216 & 0.961277 & 2.829795 & 0.0060 \\
\hline \multicolumn{5}{|c|}{ Calculated Long Term Coefficients } \\
\hline Variables & Coefficient & Standard Dev. & T-Statistic & Prob. \\
\hline ROE & -15.048678 & 3.090074 & -4.870005 & 0.0000 \\
\hline EQ_RATIO & -0.017491 & 0.022024 & -0.794202 & 0.4297 \\
\hline FOREX_BORROW & 0.002727 & 0.002044 & 1.334182 & 0.1863 \\
\hline $\mathrm{C}$ & 4.196003 & 1.313863 & 3.193639 & 0.0021 \\
\hline $\mathrm{R}^{2}$ & 0.5533 & \multicolumn{2}{|c|}{ Akaike Information Crit. } & 2.4618 \\
\hline Adjusted $\mathrm{R}^{2}$ & 0.5227 & \multicolumn{2}{|c|}{ Schwarz information criterion } & 2.6417 \\
\hline F-Statistic & 18.0850 & \multicolumn{2}{|c|}{ Durbin-Watson statistic } & 2.5339 \\
\hline \multicolumn{5}{|c|}{ TUPRS } \\
\hline \multicolumn{5}{|c|}{ ARDL(1,1,1,0) Model } \\
\hline Variables & Coefficient & Standard Dev. & T-Statistic & Prob. \\
\hline VOLATILITY(-1) & 0.470701 & 0.096935 & 4.855844 & 0.0000 \\
\hline ROE & -2.690294 & 1.745135 & -1.541597 & 0.1276 \\
\hline ROE $(-1)$ & 4.010605 & 1.821486 & 2.201832 & 0.0309 \\
\hline EQ_RATIO & -0.038633 & 0.023147 & -1.669001 & 0.0995 \\
\hline EQ_RATIO(-1) & 0.043460 & 0.023380 & 1.858859 & 0.0671 \\
\hline FOREX_BORROW & 0.000777 & 0.000493 & 1.576479 & 0.1193 \\
\hline $\mathrm{C}$ & 1.196628 & 0.486604 & 2.459141 & 0.0163 \\
\hline \multicolumn{5}{|c|}{ Calculated Long Term Coefficients } \\
\hline Variables & Coefficient & Standard Dev. & T-Statistic & Prob. \\
\hline ROE & 2.494454 & 4.728633 & 0.527521 & 0.5995 \\
\hline EQ_RATIO & 0.009119 & 0.017867 & 0.510418 & 0.6113 \\
\hline FOREX_BORROW & 0.001468 & 0.000932 & 1.575086 & 0.1196 \\
\hline $\mathrm{C}$ & 2.260781 & 0.807752 & 2.798856 & 0.0066 \\
\hline $\mathrm{R}^{2}$ & 0.3361 & \multicolumn{2}{|c|}{ Akaike Information Crit. } & 2.6608 \\
\hline Adjusted $\mathrm{R}^{2}$ & 0.2808 & \multicolumn{2}{|c|}{ Schwarz information criterion } & 2.8707 \\
\hline F-Statistic & 6.0759 & \multicolumn{2}{|c|}{ Durbin-Watson statistic } & 2.7449 \\
\hline \multicolumn{5}{|c|}{ TOASO } \\
\hline \multicolumn{5}{|c|}{ ARDL(1,1,0,0) Model } \\
\hline Variables & Coefficient & Standard Dev. & T-Statistic & Prob. \\
\hline VOLATILITY(-1) & 0.375198 & 0.103867 & 3.612283 & 0.0006 \\
\hline ROE & -4.195123 & 2.581143 & -1.625297 & 0.1084 \\
\hline ROE $(-1)$ & -3.231528 & 2.239294 & -1.443101 & 0.1533 \\
\hline EQ_RATIO & -0.027520 & 0.015129 & -1.818979 & 0.0730 \\
\hline FOREX_BORROW & 0.001937 & 0.001566 & 1.236903 & 0.2201 \\
\hline
\end{tabular}


T. C. Güleç 13/1 (2021) 100-111

\begin{tabular}{|c|c|c|c|c|}
\hline C & 3.302622 & 0.813450 & 4.060018 & 0.0001 \\
\hline \multicolumn{5}{|c|}{ Calculated Long Term Coefficients } \\
\hline Variables & Coefficient & Standard Dev. & T-Statistic & Prob. \\
\hline ROE & -11.886405 & 4.631804 & -2.566258 & 0.0123 \\
\hline EQ_RATIO & -0.044045 & 0.022959 & -1.918403 & 0.0590 \\
\hline FOREX_BORROW & 0.003100 & 0.002475 & 1.252399 & 0.2144 \\
\hline $\mathrm{C}$ & 5.285868 & 0.960009 & 5.506062 & 0.0000 \\
\hline $\mathrm{R}^{2}$ & 0.3663 & \multicolumn{2}{|c|}{ Akaike Information Crit. } & 2.8735 \\
\hline Adjusted $\mathrm{R}^{2}$ & 0.3229 & \multicolumn{2}{|c|}{ Schwarz information criterion } & 3.0535 \\
\hline F-Statistic & 8.4399 & \multicolumn{2}{|c|}{ Durbin-Watson statistic } & 2.9456 \\
\hline \multicolumn{5}{|c|}{ VESTL } \\
\hline \multicolumn{5}{|c|}{ ARDL $(1,0,0,0)$ Model } \\
\hline Variables & Coefficient & Standard Dev. & T-Statistic & Prob. \\
\hline VOLATILITY(-1) & 0.546253 & 0.092452 & 5.908478 & 0.0000 \\
\hline ROE & -1.730159 & 1.650266 & -1.048412 & 0.2979 \\
\hline EQ_RATIO & 0.033020 & 0.019474 & 1.695635 & 0.0942 \\
\hline FOREX_BORROW & 0.000155 & 0.000139 & 1.116253 & 0.2679 \\
\hline $\mathrm{C}$ & 0.655042 & 0.555144 & 1.179949 & 0.2418 \\
\hline \multicolumn{5}{|c|}{ Calculated Long Term Coefficients } \\
\hline Variables & Coefficient & Standard Dev. & T-Statistic & Prob. \\
\hline ROE & -3.813044 & 3.818106 & -0.998674 & 0.3212 \\
\hline EQ_RATIO & 0.072772 & 0.046941 & 1.550290 & 0.1253 \\
\hline FOREX_BORROW & 0.000342 & 0.000307 & 1.114261 & 0.2688 \\
\hline $\mathrm{C}$ & 1.443626 & 1.079588 & 1.337201 & 0.1853 \\
\hline $\mathrm{R}^{2}$ & 0.3443 & \multicolumn{2}{|c|}{ Akaike Information Crit. } & 2.7942 \\
\hline Adjusted $R^{2}$ & 0.3088 & \multicolumn{2}{|c|}{ Schwarz information criterion } & 2.9442 \\
\hline F-Statistic & 9.7144 & \multicolumn{2}{|c|}{ Durbin-Watson statistic } & 2.8543 \\
\hline
\end{tabular}

Following the estimation of long term coefficients, the error correction model will yield the short term coefficients for the ARDL model. The error correction model for all companies are as the following:

Error Correction Model:

$$
\begin{aligned}
\Delta \text { VOLATILITE }_{t}= & \beta_{0}+\beta_{1} \sum_{i=1}^{q} \Delta \text { VOLATILITE }_{t-i}+\beta_{2} \sum_{i=1}^{p} \Delta R O E_{t-i}+\beta_{3} \sum_{i=1}^{r} \Delta O K_{-} P_{\text {PSIF }}+\beta_{4} \sum_{i=1}^{m} \Delta Y P P_{-} F V O K_{t-i} \\
& +\gamma_{1} \text { ECM }_{t-I}+\varepsilon_{t}
\end{aligned}
$$

In this model, the error correction model(ECM) coefficient is delayed by one period behind the error term reported in long term ARDL model. The error correction coefficient $\left(\mathrm{ECM}_{\mathrm{t}-1}\right)$ is expected to be lower than one, negative, and of course, statistically significant. Here, the error correction coefficient represents the deviation period between the variables in case of a disruption to the system(such as political shocks or economic conjecture shifts). In other words, this value represents the model recuperation period following shocks.

The error correction model estimation results based on the ARDL model is demonstrated in Table 7 for all companies.

Table 7. The Error Correction Model Estimation Results Based on the ARDL Model

\begin{tabular}{|l|l|l|l|l|}
\hline \multicolumn{5}{|c|}{ ARCLK } \\
\hline \multicolumn{5}{|c|}{ ARDL(1,0,0,0) Model } \\
\hline Variables & Coefficient & Standard Dev. & T-Statistic & Prob. \\
\hline D(ROE) & -7.683335 & 2.992983 & -2.567117 & 0.0123 \\
\hline D(EQ_RATIOLER) & 0.025460 & 0.015801 & 1.611350 & 0.1114 \\
\hline D(FOREX_BORROW) & -0.006466 & 0.007681 & -0.841875 & 0.4026 \\
\hline CointEq(-1) & -0.455221 & 0.086634 & -5.254505 & 0.0000 \\
\hline \multicolumn{7}{|c|}{ EREGL } \\
\hline
\end{tabular}


T. C. Güleç 13/1 (2021) 100-111

\begin{tabular}{|c|c|c|c|c|}
\hline \multicolumn{5}{|c|}{ ARDL $(1,0,0,1)$ Model } \\
\hline Variables & Coefficient & Standard Dev. & T-Statistic & Prob. \\
\hline $\mathrm{D}(\mathrm{ROE})$ & -9.755868 & 1.785739 & -5.463211 & 0.0000 \\
\hline D(EQ_RATIO) & -0.011339 & 0.014594 & -0.777018 & 0.4397 \\
\hline D(FOREX_BORROW) & -0.000577 & 0.001390 & -0.415342 & 0.6791 \\
\hline $\mathrm{EC}(-1)$ & -0.648287 & 0.082666 & -7.842254 & 0.0000 \\
\hline \multicolumn{5}{|c|}{ TUPRS } \\
\hline \multicolumn{5}{|c|}{ ARDL $(1,1,1,0)$ Model } \\
\hline Variables & Coefficient & Standard Dev. & T-Statistic & Prob. \\
\hline $\mathrm{D}(\mathrm{ROE})$ & -2.690294 & 1.745135 & -1.541597 & 0.1276 \\
\hline D(EQ_RATIO) & -0.038633 & 0.023147 & -1.669001 & 0.0995 \\
\hline D(FOREX_BORROW) & 0.000777 & 0.000493 & 1.576479 & 0.1193 \\
\hline $\mathrm{EC}(-1)$ & -0.529299 & 0.096935 & -5.460346 & 0.0000 \\
\hline \multicolumn{5}{|c|}{ TOASO } \\
\hline \multicolumn{5}{|c|}{ ARDL $(1,1,0,0)$ Model } \\
\hline Variables & Coefficient & Standard Dev. & T-Statistic & Prob. \\
\hline $\mathrm{D}(\mathrm{ROE})$ & -4.195123 & 2.581143 & -1.625297 & 0.1084 \\
\hline D(EQ_RATIO) & -0.027520 & 0.015129 & -1.818979 & 0.0730 \\
\hline D(FOREX_BORROW) & 0.001937 & 0.001566 & 1.236903 & 0.2201 \\
\hline $\mathrm{EC}(-1)$ & -0.624802 & 0.103867 & -6.015391 & 0.0000 \\
\hline \multicolumn{5}{|c|}{ VESTL } \\
\hline \multicolumn{5}{|c|}{ ARDL $(1,0,0,0)$ Model } \\
\hline Variables & Coefficient & Standard Dev. & T-Statistic & Prob. \\
\hline $\mathrm{D}(\mathrm{ROE})$ & -1.730159 & 1.650266 & -1.048412 & 0.2979 \\
\hline D(EQ_RATIO) & -0.033020 & 0.019474 & -1.695635 & 0.0942 \\
\hline D(FOREX_BORROW) & 0.000155 & 0.000139 & 1.116253 & 0.2679 \\
\hline $\mathrm{EC}(-1)$ & -0.453747 & 0.092452 & -4.907908 & 0.0000 \\
\hline
\end{tabular}

Along with the findings from Table 7, findings for all models are summarized in Table 8.

Table 8. The Summary of Findings

\begin{tabular}{|l|c|c|c|c|c|}
\hline \multicolumn{7}{|c|}{ ARCLK } & EREGL & TUPRS & TOASO & VESTL \\
\hline ROE & Negative & Negative $^{*}$ & Insignificant & Insignificant & Insignificant \\
\hline EQ_RATIO & Insignificant & Insignificant & Negative $^{*}$ & Negative* $^{*}$ & Negative* $^{*}$ \\
\hline FOREX_BORROW & Insignificant & Insignificant & Insignificant & Insignificant & Insignificant \\
\hline \multicolumn{7}{|c|}{ Long Term Volatility } \\
\hline ROE & Negative* & Negative* & Insignificant & Negative* $^{*}$ & Insignificant \\
\hline EQ_RATIO & Insignificant & Insignificant & Insignificant & Negative* $^{*}$ & Insignificant \\
\hline FOREX_BORROW & Insignificant & Insignificant & Insignificant & Insignificant & Insignificant \\
\hline
\end{tabular}

* Term 'Negative' indicates an inverse relationship between the variable and the volatility of the company in the respective cell.

As can be seen in table 8, findings indicate that the FOREX_BORROW variable which represents foreign borrowing is utterly insignificant in both the long and short term. However, the remaining two variables ROE and EQ_RATIO which respectively represent the return on equity ratio and the equity ratio, have significance for some of the firms in both the long and short run. These findings will be evaluated in the following discussion section.

\section{Discussion}

The first thing that draws attention in the findings is the insignificance of the corporation's net foreign exchange position compared to its EBITDA. In the last decade, one of the main reasons for the vulnerability of 
the Turkish economy to the changes in the exchange rate has been the high rate of corporate foreign $\operatorname{debt(Kesriyeli~et~al.,~2005,~2011)~and~it~became~even~more~apparent~in~the~recent~} 2018$ exchange rate crisis(Taskinsoy, 2019). However, this finding is less controversial than it seems at the first glance. To begin with, the companies that are evaluated in this study are some of the most stable and well-managed companies, and the excessive foreign debt problem is an iconic problem for mainly small and medium-sized enterprises. Therefore, it is possible that these companies might have just outgrown this problem. Additionally, it takes a substantial amount of work to get an idea about the net forex position of a company, it is not readily available to the common investors as much as ROE or Equity Ratio. Even if it's calculated, net forex position has no universal optimal value to which investors can compare against, it varies significantly depending on the sector or even on the nationality of the client base of the firm.

Return of Equity plays a very significant role for Arçelik and Ereğli Demir ve Çelik companies, negatively affecting their volatility both in the short-term and in the long-term. In other words, as the ROE increases, the investors of these stocks will be less prone to a panic-sell or impulse-buy. Moreover, as a result of this stability, the stock becomes significantly less vulnerable to manipulative pumps, if not completely immune beyond a certain level. Another noteworthy finding is the long-term-only relevance of Tofas Otomobil(TOASO). As ROE improves, the volatility in long term stock prices stabilizes. This finding suggests that investors are investing in TOASO on their long-term portfolios based on rational market indicators such as ROE and Equity ratio. In short term, however, the stabilizing effect of ROE vanishes.

The equity ratio is almost the perfect symmetrical opposite of the ROE in terms of its effects on the volatility structure. Findings indicate that in short term stock market investments, equity ratio is a determining factor for 3 out of 5 companies analyzed. Similarly, a negative relationship indicates that market volatility decreases as the equity ratio increases. This can be interpreted as the investors are more concerned about the collateral safety of their investments when making short term investment decisions. However, in long term, profit generation capacity becomes significantly more of a concern.

Overall, it can be concluded that only in the short-run, the investors are primarily focused on the Equity ratio as the investors are more prone to panic selling when invested into companies that use high levels of leverage. As the Equity ratio symbolizes the debt collateral, it becomes the main indicator of volatility in the short-run. However, in both the short and the long run, ROE becomes significantly more influential over time, as it represents the profit generation capacity of the company. Additionally, it can be argued that the market does not punish the faulty debt structures in terms of foreign currency management, and this may encourage companies to overindulge in foreign currency nominated debt usage.

At this level of interaction between the price volatility and equity risk indicators, it would be safe to assume that the equity return anomaly is not a prevalent phenomenon in the Turkish stock market. 


\section{References}

Aksoy, M., \& Ulusoy, V. (2015). Analysis of relative return behaviour of Borsa İstanbul reit and Borsa İstanbul 100 index. Journal for Economic Forecasting, 1, 107-128.

Ali, A., \& Badhani, K. (2020). Beta-Anomaly: Evidence from the Indian Equity Market. Asia-Pacific Financial Markets, 1-24.

Altın, H., \& Yazan, Ö. (2016). The Effects of Trading at Sustainability Index on Stocks' Abnormal Returns: Evidence from BIST Sustainability Index in Turkey. Journal of Business ve Economic Policy, 3(4), $72-78$.

Azimli, A. (2019). Pricing the accrual effect in an emerging market. Economic Research-Ekonomska Istraživanja, 32(1), 2180-2194.

Azimli, A. (2020). Pricing the common stocks in an emerging capital market: Comparison of the factor models. Borsa Istanbul Review.

Cengiz, H., Bilen, Ö., Büyüklü, A. H., \& Damgac1, G. (2017). Stock market anomalies: The day of the week effects, evidence from Borsa Istanbul. Journal of Global Entrepreneurship Research, 7(1), 4.

Çiçek, M. (2013). The Day-of-the-Week Effect on Return and Volatility in the Turkish Stock Markets. Journal of Applied Finance and Banking, 3(4), 143.

Çıkrıkçı, M., Olcay, Z. F., \& Ozyesil, M. (2019). Short Term Underpricing Anomaly And Its Determinant Factors On Seasoned Equity Offerings: A Research On The Stocks Traded On The Borsa Istanbul (Bist). Journal Of Business Economics And Finance, 8(1), 1-16.

Çıkrıkçı, M., \& Ozyesil, M. (2018). Announcement Effect Anomaly And Its Determinants On Seasoned Equity Offerings: Evidence From Turkey. Journal Of Economics Finance And Accounting, 5(2), 168-183.

Çıkrıkçı, M., \& Ozyesil, M. (2018). Long Term Underperformance Anomaly and Its Dterminant Factors on Seasoned Equity Offerings: Evidence From Turkey. Journal of Business Economics And Finance, 7(3), 208227.

Ergun, Z. C. (2018). The Effect of Herd Behavior on Stock Markets during the Election Times: Evidence from Borsa Istanbul. 97.

Faff, R. W., Brooks, R. D., \& Kee, H. Y. (2002). New evidence on the impact of financial leverage on beta risk: A time-series approach. The North American Journal of Economics and Finance, 13(1), 1-20.

Fama, E. F. (1970). Efficient capital markets: A review of theory and empirical work. The Journal of Finance, 25(2), 383-417.

Fang, D., \& Olteanu-Veerman, D. (2019). Decompose Composite Equity Issuance Anomaly. Available at SSRN 3456079 .

Favilukis, J. Y., \& Zhang, T. (2019). One Anomaly to Explain Them All. Available at SSRN 3444342.

Fernandez, P. (2006). Levered and unlevered beta. Available at SSRN 303170.

Haykir, O. (2018). Does MAX Anomaly Exist in Emerging Market: Evidence from the Turkish Stock Market? International Journal of Economics and Financial Issues, 8(2), 148-153.

Karavardar, A. (2014). Benford's Law and an Analysis in Istanbul Stock Exchange (BIST). International Journal of Business and Management, 9(4), 160.

Kesriyeli, M., Özmen, E., \& Yiğit, S. (2005). Corporate sector debt composition and exchange rate balance sheet effect in Turkey. Central Bank of Turkey Working Paper, 5, 16.

Kesriyeli, M., Özmen, E., \& Yiğit, S. (2011). Corporate sector liability dollarization and exchange rate balance sheet effect in Turkey. Applied Economics, 43(30), 4741-4747.

Küçüksille, E., \& Özmutaf, N. M. (2015). Is There Ramadan Effect in Turkish Stock Market? Journal of Alanya Faculty of Business/Alanya Isletme Fakültesi Dergisi, 7(3). 
T. C. Güleç 13/1 (2021) 100-111

Pesaran, M. H. (1997). The role of economic theory in modelling the long run. The Economic Journal, 107(440), 178-191.

Pesaran, M. H., Shin, Y., \& Smith, R. J. (2001). Bounds testing approaches to the analysis of level relationships. Journal of Applied Econometrics, 16(3), 289-326.

Pesaran, M. H., Shin, Y., \& Smith, R. P. (1999). Pooled mean group estimation of dynamic heterogeneous panels. Journal of the American Statistical Association, 94(446), 621-634.

Sahin, S., Topaloglu, E. E., \& Ege, I. (2018). January Effect Revisited: Evidence from Borsa Istanbul and Bucharest Stock Exchange. International Journal of Economics and Finance, 10(1), 159-166.

Sari, L. A., \& Hutagaol, Y. R. (2009). Debt to equity ratio, degree of operating leverage stock beta and stock returns of food and beverages companies on the Indonesian stock exchange. Journal of Applied Finance and Accounting, 2(1), 1-12.

Taskinsoy, J. (2019). A Delicate Moment in Turkey's Economic Transition: Can Turkey Survive Mounting Economic Problems without the IMF's Bailout Package? Available at SSRN 3408520.

Toraman, C., Öztosun, E., \& Çolakoğlu, E. (2017). Testing the Day-of-the-Week Anomaly for Sectoral Turkish Stock Market. International Journal of Business Management and Economic Research, 8(1), 862-871.

Uğurlu, M., \& Demir, Y. (2016). Firma büyüklüğü anomalisinin varlı̆̆ının BİST'te test edilmesi. İşletme ve İktisat Çalışmaları Dergisi, 4(3), 106-116.

Wang, Z. (2020). The High-Volume Return Premium and Economic Fundamentals. Journal of Financial Economics (JFE), Forthcoming. 